\title{
The Relevant Past: Why the History of Management Should Be Critical for Our Future
}

\author{
STEPHEN CUMMINGS \\ TODD BRIDGMAN \\ Victoria University of Wellington
}

\begin{abstract}
When history is covered in business schools, its simplistic and evolutionary treatment goes largely unquestioned by instructors and students. To demonstrate, we show the representation of Max Weber in management texts to be dubious, a reflection of a peculiar perspective which is driven by a desire to justify the latest management ideas. However, by encouraging students to develop an ability to think critically about historical representations such as these, not only do we foster the benefits others have attributed to a greater historical awareness, we also encourage students to be more creative management thinkers for the future.
\end{abstract}

Students want to know what works and what doesn't ... they are not interested in the details of research, the historical evolution of our knowledge, or long discourses on competing ideas.

-Stephen Robbins, Managing Today, (1997: xvii).

The quotation above, from perhaps the bestselling management textbook author of our times, is indicative of an antipathy toward history within management education. Robbins has claimed that "students' interest in history is minimal" and that "the classical material in management textbooks has little value to today's students" (1997: xvii). Students want to know how to manage, not to trace the history of management research, he argues. This view resonates with broader assumptions about the ideal managers for the "new economy," free-floating identities, trained to constantly embrace change, unattached and unencumbered by history (assumptions recently critiqued by Sennett, 2006, and Petriglieri \& Petriglieri, 2009, 2010). And it may be connected to debates in this journal, and management education fora more widely, suggesting that our curricula would be more relevant (i.e., better) if it were cut free from teaching subjects for tradition's sake and if it reflected what was actually happening currently in the world of business practice (Bennis \& O'Toole, 2005; Mintzberg, 2004; Rubin \& Dierdorff, 2009; Worrell, 2009).

We are also concerned with relevance, but take a different tack. We argue that students would be more likely to have a positive impact on the future of management, if they were more engaged with the history and traditions of management-particularly that of a German sociologist who died nearly 100 years ago.

While our argument may appear counterintuitive, it is not completely new. Some recent works have linked a neglect of historical awareness to a number of key skills business students are less likely to acquire. They argue that a better understanding of management's history helps students learn the lessons of past mistakes (Wren, 1987; Thomson, 2001; Smith, 2007); or to establish a link with "great minds" (Bedeian, 2004); or connect to a "collective memory," an identity for the profession or an integrating framework (Wren, 1987; Smith, 2007); or that it provides a baseline for evaluating the extent of change in management over time (Wren, 1987; Thomson, 2001; Van Fleet \& Wren, 2005; Jones \& Khanna, 2006; Smith, 2007); or that a better understanding of history assists students to think about how supposedly "new" management practices really are (Thomson, 2001, Bedeian, 2004; Van Fleet \& Wren, 2005; Smith, 2007).

We agree with these assessments. However, it is not just the lack of teaching history that goes on in 
business schools and who is teaching it that diminishes our field, which has been previously been identified as the root of the problem (Van Fleet \& Wren, 2005). It is also the quality of teaching materials and, in particular, the lack of a critical attitude that prevents history having the positive effect on management's future that it could. Addressing this would, we argue, offer a further advantage of a historical engagement, which would result not only in better students in the present but also fundamental improvements for the future of our field. We argue that encouraging students to think critically about the construction of management history will enable them to think more creatively about what management could be.

\section{The Case of Max Weber}

According to Max Weber, bureaucracies are the ideal organizational form. [This] contrasts with more modern approaches to organizational design that claim that different forms of organizational structure may be more or less appropriate under different situations. -Jerald Greenberg and Robert A. Baron, Behavior in Organizations

(8th ed., 2003: 11)

In keeping with the antipathy expressed earlier, many management textbooks do not cover history at all. Of those that do, the quotation from Greenberg and Baron's organizational behavior textbook is not unusual. Its unwitting inaccuracies with respect to Max Weber will appear strange to those who have studied Weber.

We investigate the portrayal of Max Weber in management textbooks using this single case to provide insights into "the possibilities for and problems of learning from fragments of history" (March, Sproull, \& Tamuz, 1991: 1). It is on illustrative case, but also one that we hope will inspire further research into the uses and abuses of history in management (Siggelkow, 2007: 21-22). It is also, we believe, representative of the poor quality and lack of a critical attitude with regard to teaching management history, as well as revelatory in that a historical figure in management has never been examined in quite this way before (Yin, 2003: 39-42).

That Weber has been misrepresented in management studies has been noted on a number of occasions (Aldrich, 1979; Hill, 1981; Jackson \& Morgan, 1982; Clegg, 1992). Richard Weiss, for example, claimed that the misguided portrayal of Weber as "the most influential proponent of the bureaucratic model" (Zey-Ferrell, 1979: 48), was due to "mistranslation" (Weiss, 1983: 242). We are not setting out to describe the mistranslation or oversimplification of Weber, or anyone or anything else for that matter. We are more concerned with understanding why and how a wrong-headed configuration of Weber continues, and in some cases intensifies, in best-selling textbooks to this day, and with examining the process or system that shapes and maintains such a strawman. We seek to better understand the purposes that this strawman might serve, and thus better understand the interests that keep him afloat. And, we examine the effects of not questioning the presentation of historical figures like Weber in textbooks, as these are fed to the next generation of management thinkers who are in their formative stages. We highlight Weber to illustrate why improving the ability of aspiring managers to critically evaluate how history and historical figures may be misrepresented and misappropriated (to be critical management thinkers in this regard as well as management practitioners), can improve their ability to be creative. And, we suggest that such an approach will encourage less bounded and more substantial developments in management theory and practice for the future.

If management textbooks are our data in this quest, Michel Foucault's "counterhistorical" approaches provide us with the lenses to analyze them. Foucault is perhaps the most widely regarded critical historian of our generation. We start by outlining his approaches to historical analysis. Then we begin our analysis by utilizing Foucault's early works first to uncover the flaws in the treatment of Weber as a historical figure in management textbooks. This leads us to raise further questions. Consequently, we draw upon Foucauldian "archaeology" to try and understand how the paradigm that prevailed in the United States in the middle of the 20th century reconfigured Weber in ways that allow statements like that by Greenberg and Baron (above) to pass as the truth. Finally, we use Foucauldian "genealogy" to interrogate the contents of a popular management textbook as it has shifted through nine editions since Weber's archaeological reconfiguration. ${ }^{1}$

\section{Foucault's Critical History}

Michel Foucault (1980: 70) wrote histories that sought to counter the conventional view which saw

\footnotetext{
${ }^{1}$ We define the field of management textbooks broadly to include related subject areas such as organizational behavior, operations management, and strategy.
} 
the purpose of history to be uncovering the truth of events and the subsequent presentation of $\alpha$ "progress of consciousness" that led to (or caused) a higher level present. Foucault was critical of the role that conventional history could play in legitimating the establishment. He was more interested in examining the "history of the emergence of [the establishment's] truth games" (Florence, 1984: $314)^{2}$ and finally settled on the following definition of his type of history: "Instead of legitimating what is already known [I aim to rethink historical assumptions in order to] free thought from what it silently thinks, and so enable it to think differently" (Foucault, 1985: 9).

Consequently, Foucault did not aim for or claim to have uncovered the "whole truth" in his counterhistories, just enough to raise doubt about what was promoted as the truth of the evolution of an object. Nor did he seek to explain whole periods against a criterion of linear progress, rather to "define the conditions in which human beings "problematize" what they are, what they do, and the world in which they live" (1985: 10). He tended to start with present concerns or particular problems (e.g., madness), ask questions like "why do we treat madness as we do?" and then question the normal responses (e.g., "because our methods are the best suited to counter [or normalize] madness").

We adopt this counterhistorical approach here, beginning with the question "why do management textbooks treat history as they do?" and then questioning the normal responses: "Because it is a good representation of what actually happened" or "because it is the most effective way to educate our students."

Foucault spent decades developing different ways toward his counterhistorical aims. These ways are generally divided into three main phases: his early works, his archaeological phase, and genealogy (Burrell, 1988; Flynn, 1994). Each in some ways is a response to limitations of the phase that preceded it. A final phase, termed interpretative analytics, is sometimes added. It represents an attempt to fruitfully combine the best aspects of the earlier three, on attempt we also make here. Foucault's approaches to historical (or counterhistorical) analysis are described below.

\footnotetext{
${ }^{2}$ Florence was later revealed to be Foucault writing about himself under a pseudonym.
}

\section{Foucault's Early Works: Progressive Histories May Conceal the Truth}

Foucault's first works (1965, 1975, 1976b) critiqued psychology and psychiatry's status as sciences and their assumption that "normal" sanity is an objective, pre-existing condition. Foucault (1976b: 73) countered that "Man became a 'psychological species' only when the Age of Reason made madness a problem to be resolved and, hence, an object of inquiry." Madness, as such, was not always present, waiting to be discovered by a rigorous enough science; it was brought into being by the very practices that made such a science (psychology) possible. Thus, against histories that traced the development of objects and the separate subjects that examine them, Foucault saw subject and object as codetermining one another. He would broaden out his analysis to argue that Man did not exist until the practices constituted by the rise of humanism and the human sciences took hold (Foucault, 1970). It was the emergence of humanism, in combination with the transition into modernity, which sought to move beyond customs or traditions like the power of the sovereign or his agents to "do violence" in order to maintain control of society, which had made a problem of how control was to be upheld. This problem created the necessity for human sciences to come forth and provide "objective" universal norms that should be adhered to.

Foucault (1965: 142) highlighted the role played by psychology's history in this creation. It presented psychology as at once building on noble foundations and advancing to bring forth a new "happy age in which madness was at last recognized and treated in accordance with a truth to which we had long remained blind." But Foucault claimed that because this history is written as anticipation (the past viewed in terms of the present's "heights"), two widely accepted, but illogical, ideas took hold: the idea that madness was not recognized until it was rigorously grasped by modern science (here historians retrospectively find the origin of psychology) and the idea that the premodern approach to madness was either simplistic or erroneous, despite the fact that psychology's history has said that such an object had not been recognised yet. This, said Foucault, was no foundation for a science.

Moreover, Foucault argued that psychology's attempt to found itself as a science had not overcome a misrecognition. It had, in fact, promoted a misrecognition of a primordial understanding. $\mathrm{He}(1965,1976 b)$ claimed that the modern discov- 
ery of madness concealed real madness. Prior to modernity (e.g., during the Renaissance), our understanding was richer and more truthful.

\section{Archaeology: Every Strata Promotes Its Own Particular Truths}

Rather than addressing the history of one new science, Foucault's archaeological period sought to determine the basis "common to a whole series of scientific 'representations'" (Foucault, 1970: xixii). His focus was no longer on "how might a particular science not be a science and be keeping us from the truth?", but "what was it that motivated the human sciences to present themselves as such, to create histories that promoted this, and the consequences of this will-to-science?"

Recognizing the problem in promoting a premodern view of madness as superior, Foucault now presented the view that all truths, all conceptions of objects, are bound by the "strata" within which they are situated. He defines this strata as an episteme: "a world-view, a slice of history common to all branches of knowledge, which imposes on each one the same norms and postulates, a general stage of reason, a certain structure of thought that the men of a particular period connot escape" (Foucault 1976a: 191). And he defined archaeology as: "a history which is not that of [knowledge's] growing perfection, but rather that of its conditions of possibility" (1970: xxii). By showing the singular conditions and specific statements that different episteme would promote, he sought to critique the current arrangements that we might assume to be natural or superior. In the modern episteme, for example, human studies must satisfy the conditions of the so-called "normal" sciences to be valid. Foucault claimed this to be a terrible misfit, arguing that we should recognize the specific configuration of all fields. (Foucault's argument here is akin to that advanced recently by Khurana, 2007, with respect to how business schools sought to legitimize themselves in the 20th century by adopting the form of certain unrelated academic disciplines.)

In many ways, archaeology addresses problems with Foucault's early works. Rather than simply presenting recent views as untruthful, archaeology encourages us to identify reasons why different views emerge as truthful in different ages. By the same token, the second phase of our analysis here will seek to offer reasons why Weber, contrary to what he actually said, became a passionate advocate of bureaucracy as "the one best way" in the particular episteme of the United States in the mid-20th century.
Genealogy: The Truth Is Shaped and Maintained by the "Family Network"

In hindsight, Foucault (in Dreyfus \& Rabinow, 1982: 104) claimed that "what was missing from my work was the problem of 'discursive regime,' the effects of power proper on the enuciative play. I confused it too much with systematicity ... or something like a paradigm." To take account of this, Foucault drew on Nietzsche's view that there are no objective essential forms that can be appealed to: only chaotic webs of change and chance relations. In being afraid of this nonfoundational uncertainty, people look to historians to show that the present actually rests upon grand origins, profound intentions, and immutable necessities, and, in a circular manner, these "origins [become] the site of truth that makes possible a field of knowledge whose function is to recover it" (Foucault, 1977b). In genealogy, Foucault thus moves away from the structuralist tendencies of archaeology. All knowledge is historical as before, but all history, and consequently all development, can now only be "a series of interpretations" not related to the nature of things or the strata in which they are embedded but to particular interests (Foucault 1977b: 151).

The question then becomes "if there is nothing positive that knowledge can attach itself to, what sustains our belief in the interpretations that we take as knowledge?" Like Nietzsche, Foucault's answer was power. Not power in an obvious or direct sense necessarily, but a more subtle view of power as a "network of relations, constantly in tension, in activity" (Foucault, 1977a: 26), a network that would influence what passed for knowledge in a particular domain. Archaeology examined the truths promoted by various episteme. Genealogy would focus upon these power-knowledge relations within and across periods of time. While Foucault (1980: 52, 194) saw such networks as positive, or "perpetually creating knowledge," by producing "domains of objects and rituals of truth," he also found that they at once repressed, censored, and concealed other possibilities.

Playing an integral part in this producingrepressing relationship is the progressive history that a subject constructs out of a multiplicity of potentially contributing elements. This historical aspect produces by shaping the view and boundaries of the subject, thus making knowledge possible. However, it at once begins to shape a network that represses other interpretations. It may not be consciously developed, but this network grows as texts and their surrounding discourse educate initiates by reduplicating or reinterpreting 
events, origins, and assumptions taken to be important.

While conventional history thus aims at forming singular events into idealized and evolutionary chains of continuity (and thus, by association certain things that are discontinued), genealogy "transposes the relationship ordinarily established between the eruption of an event and necessary continuity ... records the singularity of events outside of any monotonous finality [and] disturbs what was previously considered immobile" (Foucault, 1977b: 154; Dreyfus \& Rabinow, 1983: 120). Genealogy demonstrates how a field's foundations are actually formed in a piecemeal fashion but then solidify to produce a sense of the development of knowledge while at the same time marginalizing other possibilities. Whereas archaeology showed how things would come out the same within a particular episteme, genealogy allowed for the possibility of movement as interests and power relations changed. In Foucault's words (1977b: 144), while certain points of historical "origin [would become] the site of truth" some things would be subject to reinterpretation and movement.

To begin such a genealogical counterhistory, Foucault often began by juxtaposing different quotations to highlight discontinuities. In Discipline and Punish, for example, Foucault (1977) highlighted the difference between Western ways of thinking in the 18th and 19th centuries by contrasting a grandiose description of the brutal public quartering of the regicide Damiens with a little known prison timetable outlining the inmates' mundane routines. While the discontinuities in these examples where obvious, the networks that sustained them were not too dissimilar. Foucault could argue that both were indicative of a wider social continuation of repression and control of deviance. And while modern histories of criminology might present the later as a development or increase in "humanity," Foucault's critique suggested that this was a continuity of normalization and degradation of individuality, but in a more subtle mental form than in a direct physical and public sense.

From these juxtaposed examples related to a particular problem (e.g., how best to punish deviants), Foucault would expand out to explore the diagram of power relationships that would sustain the present regime, examining how this had emerged over time. In other words, rather than plotting the past in terms of its linear path to the present, genealogical counterhistories focused on how things are constituted by a diagram or web of relations that spreads out from a particular problem to sustain understanding (Noujain, 1987).

Subsequently, the third part of our analysis of Weber's representation will focus on the problem of why management texts treat history as they do, and begin by juxtaposing statements about Weber from three editions of the same textbook. This will lead us into a broader discussion of what aspects of this Weber have been continuous and which have been adapted and changed over the 25 years and nine editions of this text. We will then outline the networks of power that may, on the one hand, sustain the continuity of this version of Weber and at once subtly reinterpret this strawman to suit the times in which each edition emerges.

\section{Analysis: Countering the Construction and Development of Weber as a 'Strawman'}

Mirroring the above organization of Foucault's approaches, our analysis of Weber's historical presentation in management textbooks is arranged in three parts: applying the thinking of his early works to question the truth of this presentation; that of his archeological period to investigate how this questionable truth was shaped by a particular episteme; and that of his genealogical inquiries to draw out the power relations that sustained and subtly shift this strowman.

\section{Early Works: How Progressive Histories of Management Conceal the Truth About Weber}

Those management textbooks that do cover the ideas of Max Weber as part of the history of their field generally present him as belonging to the classical school. Here he and other figures (most commonly Frederick Taylor) appear as an early stepping stone toward the field's present heights. Like all stepping stones, they exist on the pathway to something else, namely, in this instance, the better views of management that have been developed since. In this manner, history enables us to see gravitas, through a continuity of great thinkers applying their minds to the problem of management; and a cutting edge, through a discontinuity in the form of a series of advances beyond classical views (Cummings, 2002). In their presentations of history, these textbooks draw upon a number of histories of management that emerged in the middle of the 20th century as the subject was attempting to legitimate itself as a worthy field of inquiry. Histories like those written by Mooney (1947), George (1968), and Wren (1972), traced, for the first time, a continuity and progression from great or noble civilizations and thinkers such as the Egyp- 
tians, Romans, and Greeks; Plato, Jesus, Benjamin Franklin, and Thomas Edison, on to great management thinkers of their own times: Drucker, Fielder, Vroom, Locke and March, and Simon.

In this historical scheme, Weber is cast as an inventor and leading supporter of bureaucracy as the ideal or one-best way of organization and a whole-hearted supporter of mechanistic efficiency. $\mathrm{He}$ is generally described as a classical organization theorist or management expert and a booster of Taylorism. His major contribution to the field is often dated at 1947.

Perhaps the world's two best-selling introductory management texts inform us that Weber "considered the ideal organization to be a bureaucracy" (Stoner, Freeman, \& Gilbert, 1995), or that bureaucracy is "his ideal type" (Robbins \& Coulter, 2002: 37). Among other leading texts, Robbins and Mukerji's (1990: 42-43) treatment of Weber in Managing Organizations: New Challenges and Perspectives provides a good summary of the prevailing view. At the end of a chapter titled "The Evolution of Management Thought," a review question asks students to "Define Weber's ideal organization." They are expected to have learned that Weber's "ideal organization" exhibits bureaucratic principles. The best-selling management book of the past three decades, In Search of Excellence (Peters \& Waterman, 1982: 5), confirms that Weber "pooh-poohed charismatic leadership and doted on bureaucracy; its rule-driven, impersonal form, he said, was the only way to assure longterm survival."

In works that optimistically portray the progress of management, Weber's "love of bureaucracy" leads to complaints that he "went too far in advocating a machine-like organization" (Dale, 1967: 12); that he did not pay "attention to the human factor in organizational design" (Schwartz, 1980: 19); or that he paid "repeated homage" to the outmoded "Taylor system" (Gerth \& Mills, 1954: 261; Gross, 1964). In pessimistic works (e.g., Ritzer, 1996), Weber appears as a promoter and forerunner to the evils of dehumanization. Elsewhere, Weber is cast as an "organizational theorist" (DuBrin, 1984; Wren, 1994); a "management expert" whose "main concern [was] the nature of bureaucracies" (Clutterbuck \& Crainer, 1990: 18); or an "organizational designer." Schwartz (1980: 19) describes Weber as providing "six guidelines for organization design," which are Weber's six elements required for a bureaucracy to function effectively. In these ways, Weber is seen as both a pioneer founder whose intellect lends weight to the fledgling field and a problem to be overcome and dismissed as wrongheaded, old-fashioned or one-dimensional as the subsequent advance (i.e., discontinuity) of management thinking is traced.

However, a critical appreciation of history can, without too much effort, show these historical representations to be quite false. They conceal rather than reveal the truth. Weber was a lawyer, a historian, economist, philosopher, political scientist, and a sociologist, but he was not an organization or management expert. Such fields did not exist in his world. He never actually designed an organization. His effort was to attain a diagnosis not a prognosis of his society. Bureaucracy, while a serious concern, was not his main concern-his vision was much broader (MacRae, 1974). Further, it is unclear whether Weber was even familiar with Taylor's work. He did visit America in 1904, but Taylor was only known to a very small circle of supporters in the first decade of the 20th century and did not become widely known until 1911 in the United States and some years later abroad (Cummings, 2002). In any event, perhaps through a desire to promote simple and coherent chunks of linear progress, Weber is quite wrongly tarred with the same brush as Taylor, a very different character. Indeed, the criticism that Weber advocated efficiency to too great an extent comes despite the fact that the modern sense of efficiency as the ratio of inputs over outputs was a term foreign to Weber's German tongue at the time he wrote (Albrow, 1970).

Weber's use of the term ideal also appears to confuse management writers. Weber's "ideal types" were not in any sense good or noble or a best-case scenario. He used the term to indicate $\alpha$ model or measure against which societal development might be compared: ideal, in his language, meant not fully exemplified in reality. Hence, Weber conceived of three ideal types of authority: traditional, charismatic, and rational-legal, each of which sponsored different or competing forms of organization. In his political analysis, Weber makes it clear that a best-case scenario might be a charismatic or innovative organization in tandem with a bureaucratic organization. He even examined how traditional monarchies or aristocracies could work well. One could claim the modern contingency approach to managing organizations actually is a continuation of Weber's thinking.

Moreover, Weber was largely pessimistic about the advance of bureaucracy. History for Weber was "an eternal struggle between bureaucratic rationalization and charismatic invention" (Allen, 2004: 108). He despaired at bureaucracy's inexorable rise driving the spirit and humanity out of life (MacRae, 1974; Allen, 2004). Weber (1948: 337, 214) was sure that bureaucratic organization was "always, from 
a formal technical point of view, the most rational type," but it exhibited only a "technical superiority over other forms." This made it an obvious form only because of the particular nature of his times: the manifestation of $\alpha$ "victorious capitalism" resting on "mechanical foundations" where the "'objective" discharge of business primarily means a discharge of business according to calculable rules and without regard for persons" (Weber, 1930: 181-182; 1948: 215). Weber yearned for "charismatic figures" not bureaucrats (Allen, 2004: 108), as this passage makes clear:

Rational calculation [and bureaucratic logic] reduces every worker to a cog in this bureaucratic machine ... It is horrible to think that the world could one day be filled with nothing but those little cogs, little men clinging to little jobs and striving toward bigger ones- $a$ state of affairs ... playing an ever increasing part in the spirit of our present administrative systems, and especially of its offspring, the students. This passion for bureaucracy is enough to drive one to despair ... the great question is therefore not how we can promote and hasten it, but what can we oppose to this machinery in order to keep a portion of mankind free from [the] supreme mastery of the bureaucratic way of life (Max Weber 1909, in Mayer, 1943: 127-128).

A final notable falsehood is the dating of Weber's major contribution to management or organization theory at 1947. This is most starkly presented in a "timelime of milestones," complete with photographs of the "key contributors," on the inside front cover of Behavior in Organizations (Greenberg \& Baron, 1993). This line of portraits begins Taylor: 1911; Mayo: 1927-1932; Weber: 1947; Stogdill: 1951 ... Although no references are provided, there are similarities between this and C. S. George's "Management Continuum" first published in 1968. A condensed list of George's key figures is listed below: $350 \mathrm{BC}$ Plato . . 20 AD Jesus Christ . . 1525 Machiavelli . . 1776 Adam Smith . . . 1785 Thomas Jefferson . . . 1900 F. W. Taylor . . 1927 Elton Mayo ... 1947 Max Weber. ...

That Weber had been dead for 27 years makes 1947 seem an unusual choice for a milestone. But when one recognizes that 1947 was the year Parsons' American translation of selections of Weber's Wirtschaft and Gesellschaft appeared, and one begins to investigate the episteme within which Parsons was operating, reasons behind the creation of management textbooks' version of Weber start to be revealed.

\section{Archaeology: Every Strata Promotes Its Own Particular Truths}

The analysis in the previous section begs the question as to how the picture of Weber described above came to pass. A Foucauldian archeological approach helps to explain this, with reference to the specific set of views and values, or episteme, that emerged in the United States in the middle of the 20th century. In doing so, we shall see that 1947 is in fact an accurate dating of Weber's entry into the annals of management history. Prior to 1947, Weber, as management studies knows him, did not exist. Indeed, perhaps the first and only management teaching textbook to predate 1947, Burleigh B. Gardner's (1945) Human Relations in Industry, while focused extensively on organization and efficiency, makes no mention of Weber. He was still being created, by a very particular episteme and a peculiarly effective individual within that episteme: Talcott Parsons.

Wirtschaft and Gesellschaft was left unfinished on Weber's death. As it was planned to connect elements of Weber's other schemes one can say that his whole corpus was incomplete. So, in MacRae's (1974: 14) words, to consult Weber is often "somewhat like divination, like using a Tarot pack or the I Cheng." Hence, Marianne Weber's (1975) biography positions Weber as a great humanist and champion of good causes. Shils (1987) saw Weber as a freemarket liberal, prophetic in warning against bureaucracy. Bell (1960) and Lipset (1969) hailed Weber's view that the reconciliation between opposing forces was the desired end. Bendix (1966) claims Weber's work belongs to the intellectual heritage of European liberalism (a point discussed by most Weberian scholars, with one notable exception: Parsons). For Gerth and Mills (1948), Weber's works were romantic tragedies representing "humanist and cultural liberalism rather than economic liberalism." But, of all of the writers to interpret Weber, Parsons would be the most influential in the episteme when many of the management textbooks that our students still use were issued in their first editions (Allen, 2004).

Parsons discovered Weber in the 1920s while studying in Germany. He wrote a brilliant doctoral thesis on him, and began an English translation of Weber's essay The Protestant Ethic and the Spirit of Capitalism (1930). He returned to America and took up a position at Harvard, keen to help establish and add backbone to the fledgling field of sociology in the United States. He was also, quite naturally, keen to see the field develop in the way that he thought best, and to build his own reputation. Weber was an excellent conduit for all these 
aims, but to create the type of sociology that Parson's sought required the invention a unifying order over and above Weber's unfinished or disparate theses. Indeed, Parson's quest for a unifying logic that could explain the fundamental essences beneath social and organizational diversity, and thus explain all things, is completely in keeping with what many in the new human sciences such as sociology and ecology were seeking and offering in the middle of the 20th century (Lyotard, 1984: 50-51).

In the late 1930s, Parsons' mission led him to undertake a translation of Weber's Wirtschaft and Gesellschaft ("Work and Society"). But it is important to remember that his translation, titled The Theory of Social and Economic Organization, was in fact a translation of only some of Wirtschaft, with particular attention paid to the sections that interested him in their relation to building bases for the fledgling science of sociology, namely, those on bureaucracy and the notion of the ideal type (Mayhew, 1982). Much was left out, including Weber's own Introduction to Wirtschaft. Indeed, most of Weber's extensive writing on religion, law, and politics was not translated for many years hence.

In the years following World War II, the Parsonian interpretation took hold and spread. New sociologists and intellectuals from many other fields were drawn to Parsons' Weber: a value-free social scientist with a system above political conflicts whose triumphant rational-legal mode of authority and its bureaucratic instrument offered both rationale and hope for a more certain world. And Weber's adoption by the intelligentsia in this period after the war was further aided by Parsons' down-playing of Weber's pessimism, bleakness, and emphasis on unequal power relations with regard to rational-legal authority and bureaucracy (MacRae, 1974; Clegg, 1992; Allen, 2004).

Why would Parson's want to be positive about the power of rational authority and bureaucracy? It may have something to do with how Parsons, both a patriot and an internationalist, interpreted America's emerging role in the new episteme that would mark a shift in power from the old world to the new. This view would seem exceedingly prescient and hopeful after the Dionysian carnage that the war had wrought. Parson's saw the American paradigm in relation to the Europe as analogous to that between Greece and Rome. In notes made for a lecture at Harvard in 1933 (1933: 5-6) he outlined the similarities:

Culturally, like the Romans, we [Americans] are not creative, our genius is 'practical' ...
We like the Romans, are fairly receptive to art and taste, and to ideas, tho we do not create them. The unity of our culture is rather that of economic-legal institutions, than the type of basic 'consensus' which always seem to be involved in a creative culture... [However] ... there seems a fair possibility we may help create a social framework within which European culture can have a fairly long life.

Thus, Parsons saw the United States as an emerging exemplar of a rational-legal, and increasingly bureaucratic, society. While such a society would not in itself promote creativity (as Weber had pointed out), Parsons thought that such a society was extremely good. It provided the best chance for European culture to survive, spread, and be refined, much as the Romans had done with Greek culture. This was an optimism clung to by many during a period when many intellectuals were removing themselves from Europe and entering the United States. Parsons believed that the emergence of America as a center of power, and its management of its flourishing economic-bureaucratic society, would prove Weber's pessimism about bureaucratization wrong (Wearne, 1989).

Parsons also justified making Weber less pessimistic by pointing out that Weber used his "ideal types" in two ways: as a methodological device, a useful measuring stick to help him analyze societies; and as a means of describing what he had unearthed to be the case about a society. "That Weber called both ideal types without distinguishing them," Parsons (1929: 33) noted, "leads to serious confusion, a confusion which is especially marked in his analysis of capitalism." He then argued that Weber confused his rational-legal bureaucratic ideal with something that could happen. If he had remembered that such an ideal type could never be and realized thus that within the reality of a world where the rational-legal view dominated, creativity and spirit would still exist, perhaps even prosper, he would have been more optimistic. And, "if this error is corrected the absolute domination of the process of rationalization over the whole social process" that Weber had predicted and which had caused his angst "falls to the ground" (Parsons, 1929: 49).

Parsons' translation would correct the "error" of Weber's pessimism. The most obvious example of how this was done is his translation of Weber's use of herrschaft, which generally means domination. Parsons translated it as leadership.

Many beyond the mainstream of management studies are critical of Parsons' interpretation. Tribe (1988: 8) connects this "construction" of Weber to 
"the 'agenda setting' activities of Parsons and his associates." According to Wearne (1989: 43), "Weber became the personification of the mores for Parsons' social scientific enterprise." While MacRae (1974: 88), a little more sympathetically, argues that Parsons "extracted and elaborated something latent, a systematic sociology of great range and power ... This system ... is at once on invention and a discovery. But it is not, I think, all that there is in Weber." However, when management scholars began to systematically trace the development of management in the episteme that pervaded America in the 1950s as part of a campaign to establish management as a serious universityworthy discipline (Khurana, 2007), they latched on to Parsons' rediscovered great thinker, who had concerned himself with organization, and looked no further (Clegg, 1990). They subsequently distilled from Parsons' interpretation a Weber who contributed to the development of the fledgling field of management by defining and championing bureaucracy (George, 1968; Wren, 1972).

Further refinement of this strawman occurred as the early management textbooks borrowed from these interpretations of Parsons. However, this view of Weber is not completely fixed, and it is not all-encompassed by the episteme we have described here. Indeed, if one can find a book that draws on a range of translations of Weber, and a wider range of Weber's writings than is generally the case, from "left-field" as it were, one will find a different, more rounded Weber (e.g., Clegg, Kornberger, \& Pitsis, 2008: 485-527, 654). So, while Weber is influenced by the episteme described here, he can be otherwise. In the following paragraphs we undertake a genealogical analysis that traces Weber's malleability. It shows him subtly shaped and changed in different contexts by management studies as it evolves.

\section{Genealogy: The Truth Is Shaped and Maintained by the "Family Network"}

The key question, then, is not "Did bureaucracy ever catch on?" but rather "Is it as effective as Weber contended?" The answer, unfortunately, appears to be mixed ...

[While] it is hard to question the positive effects of [some bureaucratic] principles ... bureaucracy also extracts important costs. -Baron,

Behavior in Organizations, (2nd ed., 1986)

Weber['s] ... classical organization theory has fallen into disfavor in large part be- cause it is insensitive to human needs and not suited to a changing environment. Unfortunately, the "ideal" form of an organization, according to Weber, did not take into account the realities of the world in which it operates. -Greenberg \& Baron, Behavior in Organizations, (4th ed., 1993)

Weber's universal view of bureaucratic structure contrasts with the more modern approaches to organization design, which claim that different forms of organizational structure may be more appropriate to different situations. Also, because bureaucracies draw sharp lines between the people who make decisions (managers) and those who carry them out (workers), they are not popular today. After all, contemporary employees prefer to have more equal opportunities to make decisions ... -Greenberg \& Baron, Behavior in Organizations, (9th ed., 2008)

While an archaeological critique enabled us to understand why a peculiar view of Weber may have emerged in management textbooks, its main weakness is that the "hard and fast" nature of the episteme does not allow for or explain movement of this view. As the quotations above demonstrate, while the idiosyncratic interpretation of Weber that we have pointed to in our previous sections continues to thrive, there is also considerable room for reinterpretations.

In this section we explain why this happens, through the application of a genealogical approach to analyze of the presentation of Weber in nine editions of a popular management textbook over a 25-year period. From archaeology we draw upon the notion that the episteme in which management textbooks as a genre emerge enables and encourages statements that promote this strawman version of Weber. Unlike archaeology, however, a genealogical approach allows us to highlight the relationships and interests that sustain these interpretations of Weber in management texts and how the dynamic and static nature of this network leads to some subtle changes over time.

Through this lens, the construction of the Weber strawman can be seen to make the contemporary study of management both possible and progressive. It makes it possible by providing a historical foundation on which subsequent research can be layered, a foundation that has hardened through a 
series of interpretations that have built upon each other. This sedimentation of knowledge makes the enterprise of management research appear to both be based on noble foundations and be continually advancing. However, our genealogical analysis also reveals that the Weber strawman remains contingent and that his theorizing, as well as his contribution to history, depends on the prevailing power-knowledge relations of the day. When these shift, so too does Weber, in a way that promotes the progressive or "cutting-edge" nature of contemporary thought, as the quotations juxtaposed at the head of this section reveal. In 1993 Weber was the naïve organization theorist who failed to recognize that change and human needs would count against bureaucracy. By 2008 he has become a naïve organization theorist who advocated a universal view and an authoritarian style of management, thereby failing to foresee that contingency theory was the way forward and that employees would demand participation in decision making.

Through a genealogical critique, we can trace these processes of sedimentation and reactivation to demonstrate how the foundations of management knowledge provide a base on which knowledge can accumulate, while also being sufficiently malleable to demonstrate the relevance and superiority of contemporary thinking on the subject. In this section, we do this through an analysis of a popular management textbook Behavior in Organizations: Understanding and Managing the $\mathrm{Hu}$ man Side of Work. We surveyed a range of management textbooks which revealed a similar treatment of Weber, where he is positioned as "sincerely believing" in "his model" or "his theory" of an ideal organization, views which have subsequently been surpassed by "today's mangers" who believe that it "takes away the employee's creativity" and a contingency approach that takes us beyond the Weber's belief in "universally applicable" management practices (Robbins, 1997: 548; Robbins \& Coulter, 2005: 30-36; Robbins, Bergman, Stagg, \& Coulter 2006: 48-51). Following our survey of various textbooks, we chose to use Behavior in Organizations as an illustrative case of this broader phenomenon. This book was particularly well suited to examining how Weber's depiction, something we might assume to be solid, may shift over time. It has been through nine editions over 27 years, has had the same authorial team, is still being widely prescribed, and has described Weber's contribution in eight of its nine editions in the main body of its text (as opposed to appendices or footnotes). In analyzing the editions, we sought to identify elements of continuity and dis- continuity. The key findings with regard to the discontinuities are summarized in Table 1 below. Having identified what stayed the same and what changed, we then offer some explanations for why this might be.

The most striking continuity across all nine editions of the text is the Parsons-inspired interpretation of Weber. ${ }^{3}$ While the entry in the first edition cites Gerth and Mills' 1948 translation of Essays in Sociology, the other editions have the Henderson and Parsons translation of Theory of Social and Economic Organization (1947) as their source. ${ }^{4}$ In this Parsonian interpretation, elements of the narrative remain constant: Weber believed bureaucracy was the one best way to efficiently organize work, in the same way that Taylor believed that scientific management was the best way to perform a task. There is also continuity in the critique of Weber for lacking the complexity of mind to recognize that contingency approaches are best. Throughout all editions we are told that bureaucracies are not as efficient as Weber maintained, making them neither an "ideal" nor perfect organizational form. Finally, there is continuity in the ongoing value ascribed to Weber's contribution. While his supposed ideal bureaucracy is unrealistic in today's business environment, the theory of bureaucracy contains valuable elements which have subsequently been built upon by other scholars. This has the effect of solidifying management's position as a worthy "new science."

Descriptions of Weber as a management thinker play an important role in the narrative of management history. For management to constitute a field of study, it requires a history, which in turn requires early management thinkers. Critical analysis of Behavior in Organizations usefully demonstrates this writing of history and its gradual sedimentation. In the first edition Weber is a "sociologist" (1983: 510). By edition four (1993), however, he is also a "classical organizational theorist" (16) and an "organizational scholar" (596). These last two subject positions are productive of organizational studies (or management) as fields of study, distinct say, from psychology or sociology. Classical organizational theorist also has the effect of adding depth to the historical norrative by locating Weber within a group of supposed like-

\footnotetext{
${ }^{3}$ There is no mention of Weber in the text of the third edition, although he continued to feature in the timeline inside the front and back covers.

${ }^{4}$ In the fourth edition, this is erroneously cited as a 1921 publication, and this error remains uncorrected in all subsequent editions.
} 
TÁBLE 1

Elements of Discontinuity in Descriptions of Weber/Weber's Views

\begin{tabular}{|c|c|c|c|c|}
\hline Edition & Description of Weber & $\begin{array}{l}\text { Characteristics of the Ideal } \\
\text { Bureaucracy }\end{array}$ & Weber's View of Bureaucracy & Critique of Bureaucracy \\
\hline lst (1983) & Sociologist & $\begin{array}{l}\text { Specialization; hierarchy; abstract } \\
\text { rules; impersonality } \\
\text { qualifications; and promotion } \\
\text { on merit }\end{array}$ & $\begin{array}{l}\text { Most efficient design should be } \\
\text { adopted as widely as } \\
\text { possible. Bureaucracy } \\
\text { consistent with trend in } \\
\text { Western civilization toward } \\
\text { rationality. }\end{array}$ & $\begin{array}{l}\text { Some bureaucracies efficient but not } \\
\text { all. Thwarts upward } \\
\text { communication. Rules become } \\
\text { ends. Stifles personal growth. Not } \\
\text { the ideal form in all situations. }\end{array}$ \\
\hline 2nd (1986) & Sociologist & $\begin{array}{l}\text { Specialization; hierarchy; rules } \\
\text { impersonality; hiring by } \\
\text { qualifications; promotion by } \\
\text { merit; written records }\end{array}$ & $\begin{array}{l}\text { Weber appalled by } \\
\text { inefficiency, waste and } \\
\text { corruption. Ideal form which } \\
\text { all organizations should } \\
\text { strive for. }\end{array}$ & $\begin{array}{l}\text { Negative association with "red } \\
\text { tape." Useful for large } \\
\text { organizations. Produces rigidities. } \\
\text { Thwarts upward communication. } \\
\text { Overreliance on rules. Reduces } \\
\text { motivation. Not the ideal form in } \\
\text { all situations. }\end{array}$ \\
\hline 3rd (1990) & Weber not mentioned & & & \\
\hline 4th (1993) & $\begin{array}{l}\text { Classical organizational } \\
\text { theorist, sociologist, } \\
\text { organizational } \\
\text { scholar }\end{array}$ & $\begin{array}{l}\text { Formal rules and regulations; } \\
\text { impersonal treatment; division } \\
\text { of labor; hierarchical structure; } \\
\text { authority structure; lifelong } \\
\text { career commitment; rationality }\end{array}$ & $\begin{array}{l}\text { One best way to organize work, } \\
\text { just as scientific } \\
\text { management provides a one } \\
\text { best way to perform jobs. } \AA \\
\text { universal view of structure. }\end{array}$ & $\begin{array}{l}\text { Negative association with "red } \\
\text { tape." Not all bureaucracies } \\
\text { inefficient and unproductive. } \\
\text { Insensitive to human needs and } \\
\text { changing environment. Based on } \\
\text { Theory X assumptions. }\end{array}$ \\
\hline 5th (1995) & $\begin{array}{l}\text { Classical organizational } \\
\text { theorist, sociologist, } \\
\text { organizational } \\
\text { scholar }\end{array}$ & $\begin{array}{l}\text { Formal rules and regulations; } \\
\text { impersonal treatment; division } \\
\text { of labor; hierarchical structure; } \\
\text { authority structure; lifelong } \\
\text { career commitment; rationality }\end{array}$ & $\begin{array}{l}\text { One best way to organize work, } \\
\text { just as scientific } \\
\text { management provides a one } \\
\text { best way to perform jobs. A } \\
\text { universal view of structure. }\end{array}$ & $\begin{array}{l}\text { Negative association with "red } \\
\text { tape." Insensitive to human needs } \\
\text { and changing environment. Based } \\
\text { on Theory X assumptions. }\end{array}$ \\
\hline 6th (1997) & $\begin{array}{l}\text { Classical organizational } \\
\text { theorist, sociologist, } \\
\text { organizational } \\
\text { scholar }\end{array}$ & $\begin{array}{l}\text { Formal rules and regulations; } \\
\text { impersonal treatment; division } \\
\text { of labor; hierarchical structure; } \\
\text { authority structure; lifelong } \\
\text { career commitment; rationality }\end{array}$ & $\begin{array}{l}\text { One best way to organize work, } \\
\text { just as scientific } \\
\text { management provides a one } \\
\text { best way to perform jobs. A } \\
\text { universal view of structure. }\end{array}$ & $\begin{array}{l}\text { Negative association with "red } \\
\text { tape." Insensitive to human needs } \\
\text { and changing environment. Based } \\
\text { on Theory X assumptions. }\end{array}$ \\
\hline 7 th $(2000)$ & $\begin{array}{l}\text { Classical organizational } \\
\text { theorist, sociologist, } \\
\text { organizational } \\
\text { scholar }\end{array}$ & $\begin{array}{l}\text { Formal rules and regulations; } \\
\text { impersonal treatment; division } \\
\text { of labor; hierarchical structure; } \\
\text { authority structure; lifelong } \\
\text { career commitment; rationality }\end{array}$ & $\begin{array}{l}\text { One best way to organize work, } \\
\text { just as scientific } \\
\text { management provides a one } \\
\text { best way to perform jobs. A } \\
\text { universal view of structure. }\end{array}$ & $\begin{array}{l}\text { Negative association with "red } \\
\text { tape." Insensitive to human needs } \\
\text { and changing environment. Based } \\
\text { on Theory X assumptions. }\end{array}$ \\
\hline 8th (2003) & $\begin{array}{l}\text { Classical organizational } \\
\text { theorist, sociologist, } \\
\text { organizational } \\
\text { scholar }\end{array}$ & $\begin{array}{l}\text { Formal rules and regulations; } \\
\text { impersonal treatment; division } \\
\text { of labor; hierarchical structure; } \\
\text { authority structure; lifelong } \\
\text { career commitment; rationality }\end{array}$ & $\begin{array}{l}\text { Hierarchy of authority where } \\
\text { higher ranks issue orders } \\
\text { and lower ranks carry them } \\
\text { out. A universal view of } \\
\text { structure. }\end{array}$ & $\begin{array}{l}\text { Bureaucracies unpopular today } \\
\text { because employees prefer equal } \\
\text { opportunities. Insensitive to } \\
\text { human needs and changing } \\
\text { environment. Based on Theory X } \\
\text { assumptions. }\end{array}$ \\
\hline 9th (2008) & $\begin{array}{l}\text { Classical organizational } \\
\text { theorist, sociologist, } \\
\text { organizational } \\
\text { scholar }\end{array}$ & $\begin{array}{l}\text { Formal rules and regulations; } \\
\text { impersonal treatment; division } \\
\text { of labor; hierarchical structure; } \\
\text { authority structure; lifelong } \\
\text { career commitment; rationality }\end{array}$ & $\begin{array}{l}\text { Hierarchy of authority where } \\
\text { higher ranks issue orders. A } \\
\text { universal view of structure. }\end{array}$ & $\begin{array}{l}\text { Bureaucracies unpopular today } \\
\text { because employees prefer equal } \\
\text { opportunities. Insensitive to } \\
\text { human needs and changing } \\
\text { environment. Based on Theory X } \\
\text { assumptions. }\end{array}$ \\
\hline
\end{tabular}

minded theorists from which we have subsequently moved on. By viewing editions of the text as layers of interpretations, we can see how Weber as an organizational theorist becomes the "truth," despite this interpretation being factually erroneous, as shown earlier.

Another continuous feature in the presentation of Weber across the nine editions is the inclusion of the characteristics of Weber's ideal bureaucracy. However, there are subtle differences in the presentation of these characteristics in editions 1 and 2 compared with edition 4 onward. In the first edition, there are five characteristics, but from the second edition onward there are seven, even though the first edition clearly states that "Weber was quite precise. He felt that in its ideal form, bureaucracy was characterized by five major factors" (1983: 510). ${ }^{5}$

In addition to a change in the number of characteristics, there is a shift in their ordering in the fourth edition. Whereas the first two editions began with specialization (which become division of labor in the fourth edition onward), in the fourth

\footnotetext{
${ }^{5}$ In the first edition, rationality was not included as one of the five characteristics, although it was listed separately as an underlying theme.
} 
and all consequent editions the first feature of the ideal bureaucracy is formal rules and regulations. This characteristic was previously called abstract rules (first edition) and rules (second edition). As well as the change in label, there are changes in the description of this characteristic:

Edition 1: "All tasks would be carried out in accordance with a consistent system of abstract rules" (1983: 510).

Edition 2: "Activities should be carried out in accordance with rules and standard operating procedures" (1986: 439).

Edition 4: "Written guidelines are used to control all employees' behaviors" (1993: 17).

It would be a step too far to label this as a misrepresentation of Weber. But by modifying the description of the characteristics of the ideal bureaucracy as the subsequent editions emerge, readers of the text are more likely to draw a negative impression of the value of rules and regulations. What was in the first edition a system for delivering consistency, which could be interpreted in a positive light, becomes, by the fourth edition, the more sinister control of all behavior. Elevating it to the first characteristic of bureaucracy suggests that it was bureaucracy's most important feature. These could be considered to be minor changes, but they have the effect of reinterpreting Weber in a way that reflects the concerns of the time, nomely, the stifling effects of bureaucratic rules expressed in the common association of bureaucracies with "red tape."

Another illustration of the reinterpretation of Weber appears in edition 8 and is repeated in the ninth edition, where the references to red tape disappear and a new theme gains prominence. "Because bureaucracies draw sharp lines between the people who make decisions (managers) and those who carry them out (workers), they are not particularly popular today. After all, contemporary employees prefer to have more equal opportunities to make decisions than bureaucracies permit" (2003: 11).

This passage is of interest for several reasons. First, is the language used: "workers" in bureaucracies become "employees" in today's organizations. Second, is the assumption that it is only "workers" who receive orders in bureaucracies, which is odd given that bureaucracies are associated with multiple layers of managers receiving orders from other managers. Third, is the emphasis on "equal opportunities" demanded by today's em- ployees in contrast to bureaucracies, in which workers are forced to follow orders. This conveniently ignores the fact that most contemporary organizations are bureaucratic, to some degree.

Again, the changes here are subtle, but they are consistent with a representation of Weber to construct a binary logic in which the past is positioned as inferior to the enlightened or evolved thinking of the present day, whatever that might be. Throughout the nine editions of the text studied, there is a subtle but significant development of the historical narrative to reflect contemporary concerns. First, it was that Weber did not realize the cost of bureaucracy would likely outweigh the financial benefits. Then he did not see that people were much more "theory $\mathrm{Y}$ " than "theory X." Later, when it was contingency theory that required a counterposition, Weber was led into the discussion as the advocate of a universal approach to structure.

By 2005, it may have been the concern for empowerment and participatory styles of management that encouraged the construction of Weber as the promoter of an authoritarion style of management. It is an example of the "historical presentism" that Foucault (1977b: 148) describes in Language, Counter-Memory and Practice: "In placing present needs at the origin, the metaphysician [or historian, seeks to] convince us of an obscure purpose that seeks its realization at the moment it arises."

The overriding feature revealed by this critical analysis of the nine editions of Behavior in Organizations is the way in which Weber's work is progressively reduced and simplified, and its evaluation becomes increasingly negative. In the first edition, Weber's view of bureaucracy is placed within the context of his observation of " $a$ shift toward rationality in all spheres of life (politics, religion, economics, etc.)" (1983: 510, emphasis in original). In the second edition, it is explained that Weber's writings were a response to organizations that, at the turn of the 20th century, were characterized by "inefficiency, waste and corruption" (1986: 438). In these early editions of the text, there is a balanced evaluation of the pros and cons of bureaucracy, being well suited to some organizations but not to others. From the fourth edition onward, the location of Weber within a particular historical context gradually disappears. Students are given no indication of the changing nature of organization that Weber experienced during his lifetime and the benefits that a bureaucratic mode of thinking had brought, such as promotion being based on merit rather than family connections. It may be no random event that this characteristic of 
bureaucracy (promotion based on merit) appeared in the first two editions of the text but not from the fourth edition onward, and was replaced by "impersonal treatment," which carries a more negative connotation. Throughout subsequent editions of the text, the evaluation of bureaucracy becomes increasingly negative. By the ninth edition, the best that can be said is that "contemporary $\mathrm{OB}$ owes a great deal to Weber for his many pioneering ideas" (2008: 15).

Having identified both continuities and discontinuities in the presentation of Weber's bureaucracy theory through nine editions of Behavior in Organizations, we conclude this section by offering an explanation for why this is the case.

The construction of the strawman Weber is an ongoing process comprising processes of sedimentation of prior interpretations and a reactivation and reconstruction of Weber based on popular concerns of the present, such as the demand for autonomy and responsibility. By reconstituting Weber as the stepping stone from which we have progressed to a more enlightened view of management, management texts are able to lay claim to being at the cutting edge of management thought, our encounter with the past relevant only in so far as it demonstrates the value and superiority of contemporary ideas. Paradoxically, this rewriting of the historical narrative surrounding Weber's work occurs within the context of a reduced interest on the part of textbook authors in interrogating history, based on an assumption articulated by Robbins at the start of this article, that students are not interested in the historical evolution of management knowledge. It is this representation of history which leads us to conclude that history remains important to authors of popular mainstream management textbooks, if only so far as constructing the "bad old days" with which to compare today's liberated state of affairs. History and Weber's part in it is not a narration of past events. It is written for the present and we can expect it to be rewritten again for future generations of students, in such a way that connects to the issues of the day.

\section{CONCLUSION}

The object was to learn to what extent the effort to think one's own history can free thought from what it silently thinks, and so enable it to think differently. -Foucault, The Use of Pleasure
We should begin this conclusion by asking "does any of this really matter?" If we share Robbins' assessment of history, with which we began this article, the answer may be "no." In his textbook Managing Today, history is relegated to the appendix, "where faculty can assign it and students can read it when, or if, they wish" (1997: xvii). By this reasoning, any representation of Weber matters little, so long as students know that flatter, more flexible organizations work well and that bureaucracy does not; that contingency theory is best; deciding that employees should make their own decisions works, but making decisions for them does not, and so on.

However, if we believe that management is more diverse and more complicated than this; or we believe that what we see as "the best way" changes over time; or if we believe that it is not the latest theories that run organizations but managers making judgments about the relative merits of different ideas and how these might be interpreted, then a critical appreciation of history should be of interest and will be of great use to students. To illustrate, we can start by outlining four ways in which a student's self-awareness and judgment might be improved by thinking critically about Weber and his depiction in the history of management.

First, for students to see that a great figure like Weber struggled with the upsides and downsides of bureaucracy (as others have since) would be a better way of initiating them into our field and its long-standing complexities, than presenting Weber or other historical figures, as naïve, onedimensional strawmen. This would provide students with greater confidence to realize that there really is no one best way, not even for great thinkers, and that they, like all good managers, must always assess contexts and the strengths and weaknesses of the available options before taking action.

Second, instead of ruling out "Weberian bureaucracy" as completely bad or outmoded, recognizing this interpretation to be an oversimplification can reveal a number of intelligent possibilities. For example, recognizing that fashionable flat hierarchies are not a revolutionary discontinuity, that they are, after all, hierarchies, and that the longevity of this form indicates that it has some strengths, should help students to develop ways to make bureaucracies more human or egalitarian instead of unwittingly dismissing them wholesale. As Harold Leavitt (whose 85 years gave him an extremely broad point of view) put it, "the intensity with which we struggle against hierarchies [ultimately] only serves to highlight their durability" (Leavitt \& 
Kaufman, 2003: 98). Indeed, in the context of recent scandals it should be recognized that a major strength of a bureaucracy, when implemented well, is that it is more able to act and be seen to act ethically than other organizational forms (Du Gay, 2000). A more rounded appreciation of Weber could encourage a better appreciation that organizations can contain both bureaucratic and nonbureaucratic elements based on a clear understanding of the potential strengths and weaknesses of the form.

Third, on becoming aware of Weber's broader views, a student might begin to think critically about why he has been depicted in such a crude and expedient way. It may be human nature to put people in boxes, to see simple categories and continuities and progress and certain one best ways, when in actual fact the world of organizations is more complex and nuanced, but the case of Weber should alert students to the complexities involved in making good managerial judgments while working against such predilections to oversimplicity. Hence, a critical historical perspective con help breed greater self-awareness with regard to where students might place themselves on a spectrum of views about bureaucracy, or under what conditions might they see a bureaucracy as a good approach. Such self-awareness can work against a herd mentality that can drive unwitting phenomena such as blindly employing "best practice" in strategy development, to the global financial crisis (Nattermann, 2000; Fox, 2008). With such awareness, a manager who makes the excuse that they were only following what others told them to do or were doing becomes clearly disingenuous.

Finally, thinking critically about the way management history is related to the present should help students to see history's worth as a highly relevant repository of useful events and ideas with which to approach present issues, rather than a long gone irrelevancy best skipped over to so as to narrow their gaze on our present heights. Organizational design can be greatly aided by looking seriously at what clever minds attempted in the past. Viewed short-sightedly, General Motors may seem like on abject failure from which little inspiration may be drawn, and defeating of national morale... until one goes back and reads of the managerial innovations of Alfred Sloan and how these changed the world (Bilton \& Cummings, 2010). The GFC seems less daunting, and less of a cause for hyperbole, when seen in the light of a hundred years of crises and comebacks.

But a critical understanding of the historical presentation of Weber is not only helpful in the present; it is helpful for the future too. Beyond genealogy, Foucault took one last methodological turn. Recognizing that in veering away from archaeology's structuralism toward a view where everything was caught up in power relations which denuded any critical ability to advocate alternatives, he settled on an approach called Interpretive Analytics. This was, in effect, a combination of his earlier approaches (Dreyfus \& Rabinow, 1982). In Interpretative Analytics, Foucault's pregenealogical methods free us from a belief in our direct access to the truth of historical events: There are only interpretations. But then genealogy probes the historical and social roles that the belief in the truth of these interpretations, like the changing presentation of Weber, plays. However, genealogy is only able to highlight the power relations and "games of truth" played in the formation and maintenance of historical interpretations if it can step back again to archaeology and see a number of strata. Pasts, in which, for example, Weber could have been different.

Consequently, we argue, following Foucault, that the primary purpose of embracing management history should be to work against being restricted by what others have regarded as historical conventions, and thereby to enable "thinking differently" about management for the future. A critical Foucauldian approach can show students that their history is both questionable and malleable, and help them to recognize that the future of their subject need not be bound by unquestioned historical foundations and conventions. In other words, they are freer than what they may have thought to "think management differently." While such uncertainty might increase anxiety (one reason why management gurus sell simple solutions), we believe that the benefits of what we propose should prevail over the weight of responsibility it imposes upon aspiring managers. Concluding that the construction of Weber's role in the history of management is very much an ongoing and dynamic process, and, therefore, one that we can actively change and shape rather than being a hard and fast milestone that must be respected as foundational, enables us to promote an ability among students to think more ably about the particular complexities that they will be faced with and more creatively about how to move beyond these.

Armed with a less "black and white" understanding of history, students and academics alike might also be able to engage in more generative discussions about new organizational forms with a better understanding of substantial continuity and divergence over time (Palmer, Benveniste, \& Dunford, 2007). For example, we may be more motivated to see what could be beyond contingency 
theory, were we to recognize that Weber had already arrived at that conclusion 100 years ago. Or to see what interesting organizational blends could be built from bureaucratic and nonbureaucratic elements, or that information technology may have advanced to a point where the strengths that Weber attributed to bureaucracy might be achieved while incurring the weaknesses to lessening degrees. Or, that there may be forms that predate bureaucracy, which retroactive forces could discover and reinvent. Or, that forms exist beyond the binary logic of bureaucratic-nonbureaucratic.

While the creative possibilities that we have outlined here relate directly to the case of Weber, we have used Weber only as an example of what we believe to be a much broader phenomenon in the presentation of the progress of history in management texts. Other similarly simplistic binary interpretations of progression in management studies include centralization (old and bad) and decentralization (new and good); management (old and bad) and leadership (new and good); stability (old and bad) and change (new and good); and planning (old and bad) and emergent strategies (new and good). Many textbooks in the 1990s were sure that decentralization was "the way of the future" and that centralization was dead (Cummings, 1995). Later on, "Leaders" become those confident of their ability, willing to take risks, and the people that make things happen, while "Managers" were those threatened by change, bothered by uncertainty, and the people who prefer the status quo (Campling, Poole, Wiesner, \& Schermerhorn, 2006). This simplistic thinking complements dominant assumptions within the mainstream about organizational change: that (paradoxically) change is the only constant, that change is inherently good and stability inherently dangerous, that change must be embraced by all and will lead to success. And, at the same time, some works have set up planning as "old-hat," dull and outmoded in contrast to a more advanced approach to strategy oriented toward emergence and the vagaries of culture.

We would suggest that students should be encouraged to think critically about the construction of these simplistic notions of development, toward

\footnotetext{
${ }^{6}$ We are conscious of not falling into the trap of creating our own strawman by treating "management textbooks" as a homogenous entity. It is pleasing to see the growth of other "critical" textbooks that add a new selection of offerings to the existing mainstream textbook menu (e.g., Clegg et al., 2008; Jackson \& Carter, 2000; Knights \& Willmott, 2007; Linstead, Fulop, \& Lilley, 2004; Thomspon \& McHugh 2001).
}

actively engaging in the creation of the interesting alternatives that may lie beyond them, and toward thinking differently about what we consider to be the "relevance" of management education (Bridgman, 2007). Historical interpretations like these should not set hard and fast, and recognizing this can be liberating: It can inspire us to be more "retro-active" in order to recreate what we see as historically important, and thus, think differently in the present and for the future.

Ironically, it could be that the historical figure we could learn most from in this mission is Max Weber-not the one described in most management textbooks but the Weber who believed that contemporary institutions and their management could only be understood by knowing how they had developed in peculiar ways, over time. ${ }^{6}$ Rakesh Khurana (2007: 15) claims that the apparent originality of his thesis in From Higher Aims to Hired Hands is largely due to a lack of awareness in management circles of an approach whereby one recognizes the relationship between economic institutions and social norms - an approach that he traces back to Weber. A critical awareness of Weber, and other historical foundations, could inspire many young students toward projects like Khurana's-projects that reinvestigate the past to spark radical questioning in the present, to change our field in positive ways for the future. If we believe that making positive contributions and improving our field is important, it may be that encouraging our students to think about long dead historical figures and their representation is just as important as reflecting what managers might be doing now.

\section{REFERENCES}

Albrow, M. 1970. Bureaucracy. London: Pall Mall.

Aldrich, H. 1979. Organizations and environments. Englewood Cliffs, NJ: Prentice-Hall.

Allen, K. 2004. Max Weber: A critical introduction. London: Pluto Press.

Baron, R. A., \& Greenberg, J. 1990. Behavior in organizations: Understanding and managing the human side of work (3rd ed.). Boston: Allyn \& Bacon.

Baron, R. A. 1983. Behavior in organizations: Understanding and managing the human side of work. Boston: Allyn \& Bacon.

Baron, R. A. 1986. Behavior in organizations: Understanding and managing the human side of work (2nd ed.). Boston: Allyn \& Bacon.

Bedeian, A. G. 2004. The gift of professional maturity. Academy of Management Learning \& Education, 3: 92-98.

Bell, D. 1960. The end of ideology: On the exhaustion of political ideas in the fifties. New York: Free Press.

Bendix, R. 1966. Max Weber: An intellectual portrait. London: Methuen. 
Bennis, W. G., \& O'Toole. 2005. How business schools lost their way. Harvard Business Review, 96-104.

Bilton, C., \& Cummings, S. 2010. Creative strategy: Reconnecting business and innovation. Oxford: Wiley.

Bridgman, T. 2007. Reconstituting relevance: Exploring possibilities for management educators' critical engagement with the public. Management Learning, 38: 425-439.

Burrell, G. 1988. Modernism, postmodernism and organizational analysis 2: The contribution of Michel Foucault. Organization Studies, 9(2): 221-235.

Campling, J., Poole, D., Wiesner, R., \& Schermerhorn, J. R. 2006. Management (2nd Asia-Pacific Edition). Australia: John Wiley \& Sons.

Clegg, S. R. 1990. Modern organizations: Organization studies in a postmodern world. London: Sage.

Clegg, S. R. 1992. Postmodernism and postmodernity in organizational analysis. Journal of Organizational Change Management, 5: 8-25.

Clegg, S. R., Kornberger, M., \& Pitsis, T. 2008. Managing \& organizations: An introduction to theory and practice. London: Sage.

Clutterbuck, D., \& Crainer, S. 1990. Makers of management. London: Macmillan.

Cummings, S. 1995. Centralization and decentralization: The never-ending story of separation and betrayal. Scandinavian Journal of Management, 11: 103-117.

Cummings, S. 2002. Recreating strategy. London: Sage.

Dale, E. 1967. Organization. New York: American Management Association.

Dreyfus, H. L., \& Rabinow, P. 1982. Michel Foucault: Beyond structuralism and hermeneutics. Chicago: University of Chicago Press.

DuBrin, A. J. 1984. Foundations of organizational behavior - An applied perspective. Englewood Cliffs, NJ: Prentice-Hall.

$\mathrm{Du}$ Gay, P. 2000. In praise of bureaucracy. London: Sage.

Florence, M. 1984. Foucault, Michel, 1926 -. In G. Gutting (Ed.), The Cambridge companion to Foucault: 314-319. Cambridge: Cambridge University Press.

Flynn, T. 1994. Foucault's mapping of history. In G. Gutting (Ed.), The Cambridge companion to Foucault: 28-46. Cambridge: Cambridge University Press.

Foucault, M. 1965. Madness and civilization - A history of insanity in the age of reason. Translated by R. Howard. New York: Random House.

Foucault, M. 1970. The order of things: An archaeology of the human sciences. London: Tavistock.

Foucault, M. 1975. The birth of the clinic. New York: Vintage.

Foucault, M. 1976a. The archaeology of knowledge. New York: Harper Colophon.

Foucault, M. 1976b. Mental illness and psychology. New York: Vintage.

Foucault, M. 1977a. Discipline and punish: The birth of the prison. London: Allen Lane.

Foucault, M. 1977b. Language, counter-memory, practice. Ithaca, NY: Cornell University Press.

Foucault, M. 1980. Power/knowledge. Selected interviews and other writings 1972-77. Brighton: Harvester Press.
Foucault, M. 1985. The history of sexuality: Volume two - The use of pleasure. New York: Pantheon.

Fox, M. 2008. Herd mentality rules in financial crisis. San Diego Union Tribune, September 30.

Gardner, B. B. 1945. Human relations in industry. Chicago: Irwin.

George, C. S. 1968. The history of management thought. Englewood Cliffs, NJ: Prentice-Hall.

Gerth, H. H., \& Mills, C. W. 1948. Max Weber: Essays in sociology. London: Routledge \& Kegan Paul.

Gerth, H., \& Mills, C. W. 1954. Character and social structure, the psychology of social institutions. London: Routledge \& Kegan Paul.

Greenberg, J., \& Baron, R. A. 1993. Behavior in organizations: Understanding and managing the human side of work (4th ed.). Boston: Allyn \& Bacon.

Greenberg, J., \& Baron, R. A. 1995. Behavior in organizations: Understanding and managing the human side of work (5th ed.). Englewood Cliffs, NJ: Prentice-Hall.

Greenberg, J., \& Baron, R. A. 1997. Behavior in organizations: Understanding and managing the human side of work (6th ed.). Upper Saddle River, NJ: Prentice-Hall.

Greenberg, J., \& Baron, R. A. 2000. Behavior in organizations: Understanding and managing the human side of work (7th ed.). Upper Saddle River, NJ: Prentice-Hall.

Greenberg, J., \& Baron, R. A. 2003. Behavior in organizations: Understanding and managing the human side of work (8th ed.). Upper Saddle River, NJ: Prentice-Hall.

Greenberg, J., \& Baron, R. A. 2008. Behavior in organizations: Understanding and managing the human side of work (9th ed.). Upper Saddle River, NJ: Pearson Prentice-Hall.

Gross, B. M. 1964. The managing of organizations: The administrative struggle. New York: Macmillan.

Hill, S. 1981. Competition and control at work. Cambridge, MA: MIT Press.

Jackson, J., \& Morgan, C. 1982. Organization theory (2nd ed.). Englewood Cliffs, NJ: Prentice-Hall.

Jones, G., \& Khanna, T. 2006. Bringing history (back) into international business. Journal of International Business Studies, 37: 453-468.

Khurana, R. 2007. From higher aims to hired hands. The social transformation of American business schools and the unfulfilled promise of management as a profession. Princeton, NJ: Princeton University Press.

Knights, D., \& Willmott, H. 2007. Introducing organizational behaviour and management. London: Thomson Learning.

Leavitt, H., \& Kaufman, R. 2003. Why hierarchies thrive. Harvard Business Review, 81(3): 96-102.

Linstead, S., Fulop, L., \& Lilley, S. 2004. Management and organization: A critical text. Basingstoke: Palgrave.

Lipset, S. M. 1969. The end of ideology. In C. Waxman (Ed.), The end of ideology debate. New York, Simon and Schuster.

Lyotard, J. F. 1984. The postmodern condition: A report on knowledge. Manchester: Manchester University Press.

MacRae, D. G. 1974. Weber. London: Fontana.

March, J. G., Sproull, L. S., \& Tamuz, T. 1991. Learning from samples of one or fewer. Organization Science, 2: 1-13. 
Mayer, J. P. 1943. Max Weber and German politics. London: Faber \& Faber.

Mayhew, L. H. (Ed.). 1982. Talcott Parsons: On institutions and social evolution. University of Chicago Press.

Mintzberg, H. 2004. Managers not MBÄs. London: Pearson

Mooney, J. D. 1947. Onward industry: The principles of organization. New York: Harper \& Row.

Nattermann, P. 2000. Best practice does not equal best strategy. McKinsey Quarterly, 2: 22-31.

Noujain, E. G. 1987. History as genealogy: An exploration of Foucault's approach to history. In A. P. Griffiths (Ed.), Contemporary French philosophy. Cambridge: Cambridge University Press.

Palmer, I., Benveniste, J., \& Dunford, R. 2007. New organizational forms: Towards a generative dialogue. Organization Studies, 28(12): 1829-1847.

Parsons, T. 1929. 'Capitalism' in recent German Literature: Sombart and Max Weber II. Journal of Political Economy, 37(1): 31-51.

Parsons, T. 1933. Lecture Outline. 3 May 1933. 7 pages (typed notes). Course material: lecture notes, outlines, reading lists, etc. 1930s-1960s (HUG (FP) - 15.65 Box 1).

Peters, T. J., \& Waterman, R. H. 1982. In search of excellence: Lessons from America's best-run companies. New York: Harper \& Row.

Petriglieri, G., \& Petriglieri, J. 2009. Business schools need $a$ broader mandate. BusinessWeek, Viewpoint, June 1.

Petriglieri, G., \& Petriglieri, J. 2010. Identity workspaces: The case of business schools. Academy of Management Learning \& Education, 9: 41-60.

Ritzer, G. 1996. The McDonaldization of society: An investigation into the changing character of contemporary social life. Thousand Oaks, CA: Pine Forge Press.

Robbins, S. P. 1997. Managing today. Upper Saddle River, NJ: Prentice Hall.

Robbins, S. P., \& Coulter, M. K. 2002. Management (7th ed.). Upper Saddle River, NJ: Prentice-Hall.

Robbins, S. P., \& Coulter, M. K. 2005. Management (8th ed.). Upper Saddle River, NJ: Prentice-Hall.

Robbins, S. P., Bergman, R., Stagg, I., \& Coulter, M. 2006. Management (4th ed.). Sydney: Pearson Education Australia.

Robbins, S. P., \& Mukerji, D. 1990. Managing organizations: New challenges and perspectives. New York: Prentice-Hall.

Rubin, R. S., \& Dierdorff, E. C. 2009. How relevant is the MBA? Assessing the alignment of required curricula and required managerial competencies. Academy of Management Learning \& Education, 8: 208-224.

Schwartz, D. 1980. Introduction to management: Principles, practices, and processes. New York: Harcourt Brace.
Sennett, R. 2006. The culture of the new capitalism. New Haven, CT: Yale University Press.

Shils, E. 1987. Max Weber and the world since 1920. In W. Mommsen \& J. Oesterhammel (Eds.), Max Weber and his contemporaries. London: Allen and Unwin.

Siggelkow, N. 2007. Persuasion with case studies. Academy of Management Journal, 50: 20-24.

Smith, G. E. 2007. Management history and historical context: Potential benefits of its inclusion in the management curriculum. Academy of Management Learning \& Education, 6: 522-533.

Stoner, J. A. F., Freeman, R. E., \& Gilbert, D. R. 1995. Management (6 ed.). London: Prentice-Hall.

Thompson, P., \& McHugh, D. 2001. Work organisations (3rd ed.). London: Palgrave.

Thomson, A. 200l. The case for management history. Accounting, Business \& Financial History, 11(2): 99-115.

Tribe, K. 1988. Translator's introduction. In W. Hennis, Max Weber, essays in reconstruction. London: Allen \& Unwin.

Van Fleet, D. D., \& Wren, D. A. 2005. Teaching history in business schools: 1982-2003. Academy of Management Learning \& Education, 4: 44-56.

Wearne, B. C. 1989. The theory and scholarship of Talcott Parsons to 1951: A critical commentary. Cambridge: Cambridge University Press.

Weber, M. 1975. Max Weber: A biography. New York: John Wiley.

Weber, M. 1930. The Protestant ethic and the spirit of capitalism. London: Allen-Unwin.

Weber, M. 1947. The theory of social and economic organizations. Translated by A. M. Henderson and T. Parsons. New York: Free Press.

Weber, M. 1948. From Max Weber: Essays in sociology. Translated by H. Gerth and C.W. Mills. London: Routledge.

Weiss, R. M. 1983. Weber on bureaucracy: Management consultant or political theorist? Academy of Management Review, 8(2): 242-248.

Worrell, D. L. 2009. Assessing business scholorship: The difficulties in moving beyond the rigor-relevance trap. Academy of Management Learning \& Education, 8: 127-130.

Wren, D. A. 1972. The evolution of management thought. New York: Wiley.

Wren, D. A. 1987. Management history: Issues and ideas for teaching and research. Journal of Management, 13(2): 339-350.

Wren, D. A. 1994. The evolution of management thought (4th ed.). New York: Wiley.

Yin, R. K. 2003. Case study research: Design and methods. Thousand Oaks, CA: Sage.

Zey-Ferrell, M. 1979. Dimensions of organizations. Glenview, IL: Scott, Foresman.

Stephen Cummings (PhD, University of Warwick, stephen.cummings@vuw.ac.nz) is professor of strategy at Victoria University of Wellington, New Zealand. His current research interests include the history of the formation of management and of business schools, and alternative approaches to strategy formulation and communication.

Todd Bridgman (PhD, University of Cambridge, todd.bridgman@vuw.ac.nz) is a senior lecturer at the Victoria Management School, Victoria University of Wellington, New Zealand. His current research interests include critical perspectives on management education and organisational change. 